\title{
Flow Injection Amperometric Determination of Phenol and Chlorophenols at Single Wall Carbon Nanotube Modified Glassy Carbon Electrode
}

\author{
Negussie Negash ${ }^{1}$, Hailemichael Alemu ${ }^{2 *}$, Merid Tessema ${ }^{1}$ \\ ${ }^{1}$ Department of Chemistry, Addis Ababa University, Addis Ababa, Ethiopia \\ ${ }^{2}$ Department of Chemistry and Chemical Technology, National University of Lesotho, Roma, Lesotho \\ Email: "hm.alemu@nul.ls,
}

Received November 16, 2013; revised December 21, 2013; accepted December 30, 2013

Copyright (C) 2014 Negussie Negash et al. This is an open access article distributed under the Creative Commons Attribution License, which permits unrestricted use, distribution, and reproduction in any medium, provided the original work is properly cited. In accordance of the Creative Commons Attribution License all Copyrights (c) 2014 are reserved for SCIRP and the owner of the intellectual property Negussie Negash et al. All Copyright (C) 2014 are guarded by law and by SCIRP as a guardian.

\begin{abstract}
Single wall carbon nanotube modified glassy carbon electrode (SWCNT/GCE) was used for flow-injection analysis (FIA) for phenolic compounds (phenol (P), 4-chlorophenol (CP), 2,4-dichlorophenol (DCP), 2,4,6-trichlorphenol (TCP) and pentachlorophenol (PCP)). Experimental variables such as the detection potential, flow rate and $\mathrm{pH}$ of the carrier solution, $0.1 \mathrm{M}$ sodium acetate, were optimized. Under these conditions, the designed electrode showed a very good performance for the amperometric measurements, with no need to apply a cleaning or pre-treatment procedure. The operational stability was tested with 20 repetitive injections of each analyte and was found to be good. The analytical performance of the SWCNT/GCE electrode under flow through conditions was tested and was found to be impressive. When it is compared with other enzymatic and non-enzymatic sensors, it shows wider dynamic range for the detection of phenolic compounds with low limits of detection. These results suggest that the method is quite useful for monitoring and analyzing phenols and chlorophenols.
\end{abstract}

\section{KEYWORDS}

Single Wall Carbon Nanotube Modified Electrode; Phenol and Chlorophenols; Amperometry; Flow Injection Analysis

\section{Introduction}

Modification of conventional electrode surfaces is necessary in sensor constructions as they can be used as a sensing platform. In electrochemistry, carbon based electrodes have been widely used, because of their low cost, low background current, wide potential window and biocompatibility [1,2]. Among several forms of carbon used as electrochemical sensors, carbon nanotubes (CNT) stand out as the most promising material for the development of sensors due to their fast electron transfer kinetics and enhanced electronic properties. CNTs also display high electrical conductivity, chemical stability and mechanical strength. CNT modified electrodes exhibit low limit of detection and fast responses due to their high surface area, low over voltage and rapid electrode kinet-

${ }^{*}$ Corresponding author. ics [2-7].

The two main classes of CNTs are single-walled carbon nanotubes (SWCNTs) and multi-walled carbon nanotubes (MWCNTs). SWCNTs are $\mathrm{sp}^{2}$ hybridized carbon that possesses a cylindrical nano-structure that has only one single layer of graphene cylinder [8]. SWCNTs can be classified as either semi-conducting or metallic allotropes depending on the chirality [2]. MWCNTs have a complex structure with each carbon layer having different chiralities and electronic properties and consist of several layers of graphite cylinders that are concentric tubes encircling one another [4]. CNTs have attracted increasing interest in the application of CNTs based sensors in the detection and determination of phenols and phenolic compounds [3,9-12]. Phenolic compounds include a large class of compounds that are common in nature. They are widely distributed in fruits and vegetables with varying 
phenolic content [13]. They are partly formed as a result of biodegradation of natural compounds like humic acids, tannins and lignins. Phenolics are a complex group of substances that provide flavor and color characteristic of food, since most of them occur in food products. Many of the benefits associated with consumption of phenolrich foods are associated with their antioxidant activities which are determined by their reactivity as hydrogen or electron donating agent [14-16]. Phenols and phenol derivatives are commonly used in the manufacture of dyes, plastics, drugs, explosives, detergents, paper mills and in the petroleum industry. They are used to manufacture chemicals that are used as preservatives for woods, textile and leathers [17] and have a considerable application in agriculture as herbicides, insecticides and fungicides. Most phenolic compounds, especially chlorophenols and nitro phenols, are toxic, highly resistant to biological degradation and persistent in the environment. Chlorinated phenols such as 2-chlorophenoll, 2,4-dichlorophenol, 2,4, 6-trichlorophenol and pentachlorophenol are toxic and possess carcinogenic and immunosuppressive properties [18]. As a result, the United State Environmental Protection Agency (EPA) and the European Union have included these phenolic compounds in their list of primary pollutants [19-21].

The applications of phenol and its derivatives represent potential source of pollution and are usually found in waste waters' effluents from different factories using phenolic compounds and manufacturing petrochemicals [17, 22]. Phenol contamination of water bodies also has serious environmental implications because of the damaging effects it has on aquatic organisms [22] including algae and aquatic spermatophytes. Phenolic derivatives are released to the environment, and their identification and quantifications are of great importance in environmental monitoring.

Various methods, such as high-performance liquid chromatography with different detectors, liquid chromatography-mass spectrometry, gas chromatography mass spectrometry, capillary electrophoresis and fluorometry, have been reported for the determination of phenols and phenol derivatives [15,17,18,23-30]. These conventional methods are sensitive, reliable, specific and precise. In spite of their advantage, most of these techniques need expensive instrumentations, require skilled technicians and are time-consuming, and some require derivatization procedures.

The sensitive, rapid and precise determination of phenols and its derivatives is of growing interest in environmental control and protection. Flow injection analysis (FIA) has been widely used for the determination of phenolic compounds because of its outstanding features of high sampling rate, small sample volumes, good accuracy and precision of results, high reproducibility, high versatility, high robustness and easy automation [31-33]. A number of research out-puts were published on the amperometric detection of phenol and its derivatives using tyrosnase (Tyr) [31,34], laccase [35,36], horse-radish peroxidase $[37,38]$, as well as poly phenol oxidase based electrochemical sensors coupled with flow-injection analysis for the determination of phenol and phenol derivatives. These enzymes were either individually immobilized or a composite multienzyme system immobilized on conventional electrodes to determine phenolic compounds [39]. The analytical performances of enzyme based biosensors strongly depend on the immobilization procedure and accuracy, sensor-to-sensor reproducibility and operational life times and are drastically affected by enzyme stability [40]. The poor biocompatibity and low capacity for immobization of these enzymes also result in inefficient performance of some biosensors [41].

To our understanding, CNT modified electrodes for the determination of phenols and chlorophenols as an electrochemical sensor for flow injection amperometric analysis system have not been reported. The simplest electrochemical flow detector, SWCNT modified GC electrode, was developed successfully for the determination of phenols and chlorophenols. The parameters such as operational potential, $\mathrm{pH}$ and flow rates were investigated and optimized.

\section{Experimental}

\subsection{Reagents and Apparatus}

SWCNT was obtained from Saarchem Holparo Analytical (Pty) Ltd. Phenol, 4-chlorophenol, 2,4-dichlorophenol, 2,4,6-trichlorophenol, and pentachlorophenol were purchased from Fluka (Buchs, Switzerland). Acetic acid and DMF were obtained from (Merck). O-nitrophenol was from Riedelde Haen and other chemicals were obtained from SAAR-CHEM, Republic of South Africa (RSA). Helium gas (Air Products, RSA) was employed for the de-aeration of the carrier solution. All chemicals were analytical grade and were used without further purifications. Ultrapure water of resistivity $18.2 \mathrm{M} \Omega \cdot \mathrm{cm}$ was obtained from ELGA PURELAB Option-Q (UK) water purification system and was used throughout.

Electrochemical measurements were performed using Epsilon Electrochemical Analyzer (BASi) attached to BAS C2 cell stand (BASi Instrumentation, USA). A conventional three electrode cell was used for measurements, with a bare glassy carbon electrode (3 $\mathrm{mm}$ diameter, BASi) or SWCNT/GCE used as the working electrode, $\mathrm{Ag} / \mathrm{AgCl}(3 \mathrm{M} \mathrm{NaCl})$ (BASi) as the reference electrode and a platinum wire auxiliary electrode (BASi). The flow system consisted of a BAS pump (Model PM-92E; USA), a sample injection valve, and a thin-layer electrochemical detector (BASi LC-4C, USA), with a flow-through cell. 
The electrochemical detector was connected to the Epsilon Electrochemical Analyzer. Two GCE modified with SWCNT (in series configuration) were used as working electrodes, while Ag/AgCl electrode (3 M NaCl) (RE-1; BAS) served as the reference electrode. The counter electrode was the bulk plate of the cell, made of stainless steel. The thickness of the layer in the cell was 0.0127 $\mathrm{cm}$. The $\mathrm{pH}$ of the solutions was measured using HANNA HI 8314 pH-meter.

\subsection{Fabrication of SWCNT/GCE}

The modified working electrode, SWCNT/GCE, was prepared by dispersing SWCNT in DMF (1 mg: $1 \mathrm{~mL}$ ratio) and sonicated with ultrsonication water bath for an hour [42]. Before surface modification, the bare glassy carbon electrode was polished with a 0.3 and $0.05 \mu \mathrm{m}$ alumina slurry and washed with distilled water several times and sonicated for 3 minutes. The SWCNT film was prepared by casting a $20 \mu \mathrm{L}$ of the dispersed solution over the bare GCE and dried overnight at room temperature.

\subsection{Measurements}

For the voltammetric measurements, $10 \mathrm{~mL}$ solution that contain $1 \times 10^{-4} \mathrm{M}$ phenol and chlorophenols, in a $0.1 \mathrm{M}$ acetate buffer supporting electrolyte, were transferred to the cell. The cyclic voltammetry experiments were run after stirring the spiked solution for 30 seconds. The measurements were performed by scanning the potential from 0 to $1.2 \mathrm{~V}$ and back at a scan rate of $50 \mathrm{mV} \cdot \mathrm{s}^{-1}$ for all the studied phenols. A $0.1 \mathrm{M}$ sodium acetate buffer was also used as a carrier solution in the flow through experiments after de-aerating the solution with helium gas. A $20 \mu \mathrm{L}$ of the sample solutions were injected at every experimental run.

\section{Results and Discussion}

\subsection{Electrochemical Characterization of Phenol at SWCNT/GCE}

The electrochemical characteristic of phenol at a bare glassy carbon electrode was studied using cyclic voltammetry. Figure 1 shows subsequent current/potential curves recorded for $1 \times 10^{-4} \mathrm{M}$ phenol in a $0.1 \mathrm{M}$ sodium acetate buffer ( $\mathrm{pH}$ 6.0) in the potential range of 0 to $1.2 \mathrm{~V}$. Due to the electro-deposition of non-conductor oxidation product of phenol i.e. polymers [43-45], the oxidation peak at the bare glassy carbon electrode decreased markedly with successive cycles. The response disappeared totally after three cycles owing to the adsorption of phenol oxidation products which decrease the available electrode surface area. Normally the oxidation of phenol produces conducting monomers and non conducting poly- mer as shown by Scheme 1, which is responsible for such electrode fouling [46,47].

In the absence of phenol, only with the sodium acetate buffer solution, the bare GCE Figure 1(a), and SWCNT/ GCE, Figure 1(c) showed no oxidative or reduction peak, while the back ground current at SWCNT/GCE is much larger than the bare electrode. This indicates that the SWCNTs increased the effective surface area of the modified electrode [9] and also proved that SWCNTs have been successfully immoblized onto the bare electrode surface. For $1 \times 10^{-4} \mathrm{M}$ phenol solution of Figure 1 (b), the voltammogram at the bare GCE showed irreversible behavior with $E_{\mathrm{pa}}=0.851 \mathrm{~V}$ [46], and at the SWCNT/ GCE there was also an irreversible peak, Figure 1(d), with $E_{\mathrm{pa}}=0.686 \mathrm{~V}$ with about twelve times intensified peak current compared to the bare GCE. This indicates that SWCNTs can greatly enhance the electron transfer rate, with significantly reduced over-potential. This implies that the SWCNTs show excellent electrocatalytic effect towards phenol oxidation.

On the other hand ten successive cyclic voltammetric curves of phenol recorded at SWCNT/GCE as shown in Figure 2 demonstrate a quite interesting behavior. During the first positively going scan, phenol undergoes oxidation in a single step, peak $1_{\mathrm{a}}$, at $E_{\mathrm{p} 1 \mathrm{a}}=+0.69 \mathrm{~V}$. On the negative going scan, two reduction peaks occurred, peak $3_{\mathrm{c}}$, at $E_{\mathrm{p} 3 \mathrm{c}}=+0.36 \mathrm{~V}$ and peak $2_{\mathrm{c}}$, at $E_{\mathrm{p} 2 \mathrm{c}}=+0.10 \mathrm{~V}$.

The cathodic peak corresponds to the reduction of the two phenol oxidation products, ortho-quinone to orthophenol (catechol), peak 3 , and para-quinone to paraphenol (hydroquinone), peak $2_{c}$, Scheme $1[12,46]$. The second scan in the positive potential direction shows two anodic peaks: peak $2 \mathrm{a}$ at $E_{\mathrm{p} 2 \mathrm{a}}=+0.13 \mathrm{~V}$, and peak $E_{\mathrm{p} 3 \mathrm{a}}=$ $+0.39 \mathrm{~V}$, indicating the reversibility of the two peaks [46, 12]. This shows that the electroxidation path way of phenol at the modified electrode is different from that of the

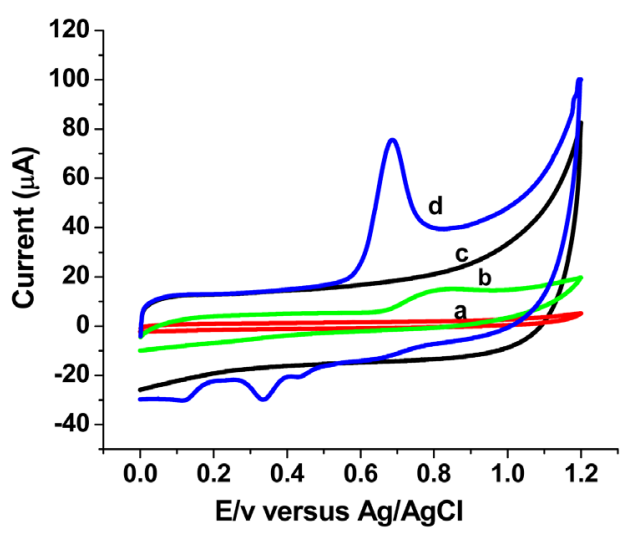

Figure 1. Cyclic voltammograms: $0.1 \mathrm{M}$ acetate buffer pH 6 base electrolyte at bare GCE (a); $0.1 \mathrm{M}$ acetate buffer pH 6 base electrolyte at SWCNT/GCE (c); $1 \times 10^{-4} \mathrm{M}$ phenol at bare GCE (b); and $1 \times 10^{-4} \mathrm{M}$ phenol at SWCNT/GCE recorded at Scan rate, $50 \mathrm{mV} \cdot \mathrm{s}^{-1} ; \mathrm{pH}$. 


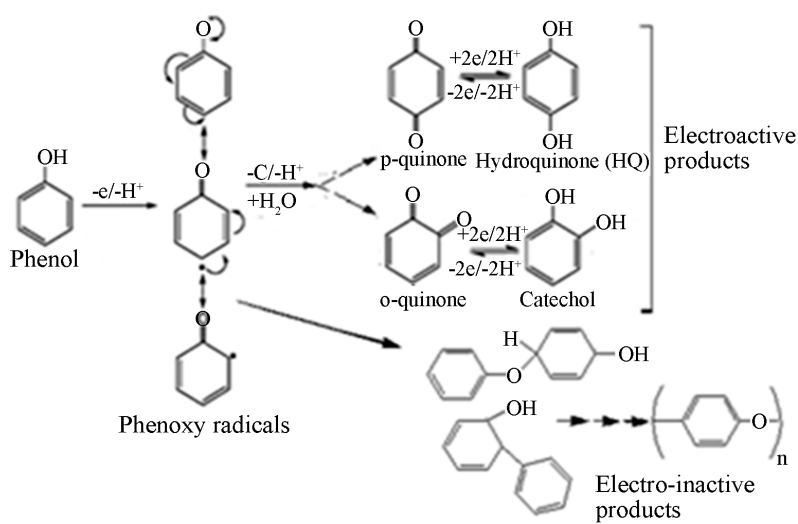

Scheme 1. Phenol electro-oxidation and polymerization processes [12].

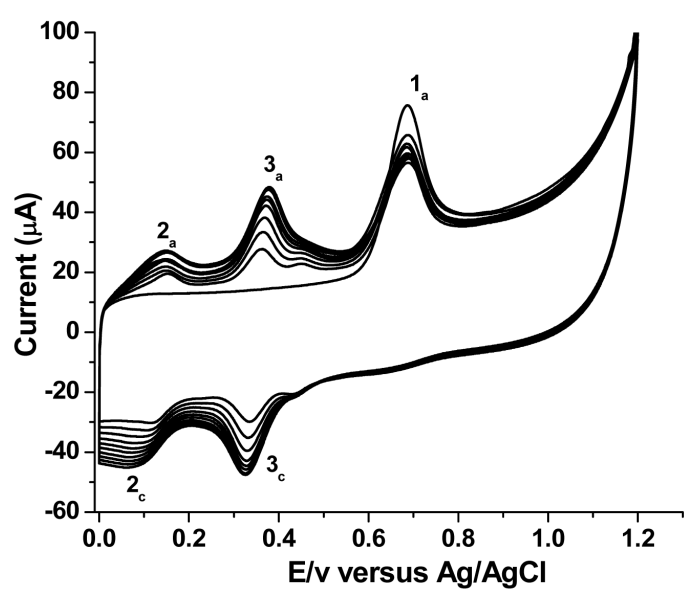

Figure 2. Overlay of 10 successive cyclic voltammograms for $1 \times 10^{-4} \mathrm{M}$ phenol at $50 \mathrm{mV} \cdot \mathrm{s}^{-1}$.

bare GCE. At the modified electrode, unlike at the bare GCE, the oxidation peak current of phenol $1_{\mathrm{a}}$ shows a small decrease in intensity after the first scan, but is then practically remains constant for the subsequent 8 scans. The peak potential observed ranged between $0.685-0.690 \mathrm{~V}$ versus $\mathrm{Ag} / \mathrm{AgCl}$ and this makes it suitable to be used as an electrochemical flow through detector for the determination of phenol and chlorophenols in flow injection system.

\subsection{Flow Injection Analysis}

The electrochemical performance of the glassy carbon electrode modified with SWCNT was studied in $0.1 \mathrm{M}$ acetate buffer solution using flow injection analysis. The parameters optimized to determine phenol and chlorophenols were: potential, flow rate and $\mathrm{pH}$. For comparison, similar experiments were carried out using bare GCE during potential optimization.

\subsubsection{Effect of Potential on the Response of SWCNT/GCE Electrode}

The influence of the applied potential on the amperome- tric responses of the two electrodes for phenol and chlorophenols was examined using flow injection system. Figure 3 shows the hydrodynamic voltammograms obtained at bare GCE and SWCNT/GCE for $1 \times 10^{-4} \mathrm{M}$ phenol and chlorophenols, respectively. The influence of the applied potential on phenol and chlorophenols oxidation was studied over a potential range of $0.1-1.0 \mathrm{~V}$. The maximum oxidation potential observed was between 0.6 and $0.8 \mathrm{~V}$. This was similar to the maximum current observed between 0.65 to $0.80 \mathrm{~V}$ for 2,4,6-trichlorophenol [47]. As it is shown in Figure 3, the effect of the SWCNT/GCE can be clearly seen by the significant increase of the peak current compared to the bare GCE. Such effect is attributed to the fast electronic transfer offered by SWCNT which enhances the oxidation of phenols and chlorophenols $[8,48]$. The bare glassy carbon electrode responded favorably only to the first three injections with low amperometric current and exhibited a poorly defined response as reported [9].

\subsubsection{Effect of $\mathrm{pH}$ on the Response of SWCNT/GCE}

The effect of $\mathrm{pH}$ on the performance of GCE modified with SWCNT was evaluated by using $0.1 \mathrm{M}$ acetate buffer solution over the $\mathrm{pH}$ range of 3 - 10 for phenol and chlorophenols. For each analyte the amperometric response was recorded at a fixed potential. The result shows that, (Figure 4), the amperometric response increases with increasing $\mathrm{pH}$ until it reaches the range of pH 6 to 7.5, where the higher peak current values were observed. The highest peak current for 2,4,6-trichlorophenol was observed at about $\mathrm{pH} 9$. The current decreases as the $\mathrm{pH}$ increases. The optimum $\mathrm{pH}$ range that gave maximum current is similar to that previously reported for both enzymatic and mediated electrochemical reactions at carbon nanotubes [49], a screen-printed sensor based on immobilization of laccase, peroxidase, and tyrosinase for monitoring phenols $[39,50]$ and a wide optimum $\mathrm{pH}$ of 5 - 8 for free enzyme [51]. It seems that the SWCNT/GCE composite has not altered the optimum $\mathrm{pH}$ of phenol and chlorophenols oxidation significantly. For further studies, $\mathrm{pH}$ of 7 for phenol and pentachlorophenol, pH 6 for 4-chlorophnol and 2,4-dichlorophenol and pH 9 for trichlorophenol were selected, respectively.

\subsubsection{Effect of Flow Rate on the Response of SWCNT/GCE}

One of the basic parameters which influence the performance of flow injection analysis is flow rate. The flow rate affects detection limit, sensitivity, and accuracy of analysis. The influence of flow rate on the amperometric signal was examined in the $0.1-2.0 \mathrm{~mL} \cdot \mathrm{min}^{-1}$ range for all analytes at SWCNT/GCE. To investigate the effect of flow rate, $20 \mu \mathrm{L}$ of $1 \times 10^{-4} \mathrm{M}$ phenol and chlorophenols were injected at various flow rates. The applied potential 

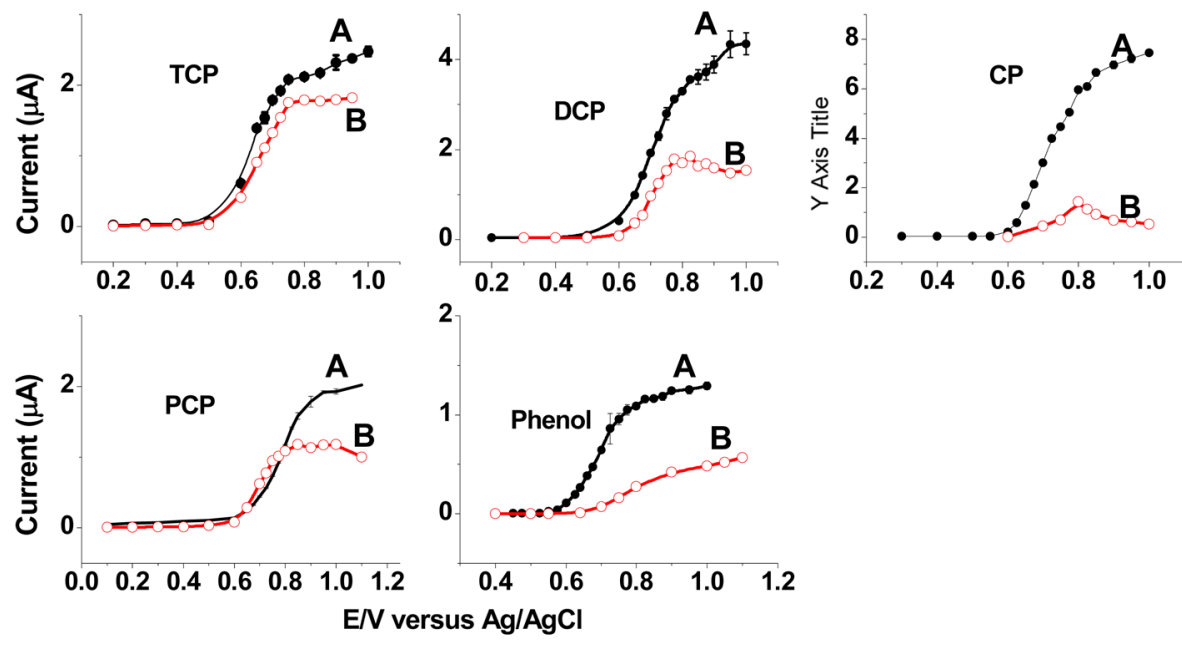

Figure 3. Dependence for $1 \times 10^{-4} \mathrm{M}$ solutions of the current response in FIA on the applied working potential at GCE (B) and SWCNT/GCE (A), 2,4,6-trichlorphenol (TCP), 2,4-dichlorophenol (DCO), 4-chlorophenol (CP), pentachlorophenol (PCP) and phenol: Flow rate, $1.0 \mathrm{~mL} \cdot \mathrm{min}^{-1}$; carrier solution: sodium acetate buffer $(0.1 \mathrm{M})$; pH 6, injection volume $20 \mu \mathrm{L}$.

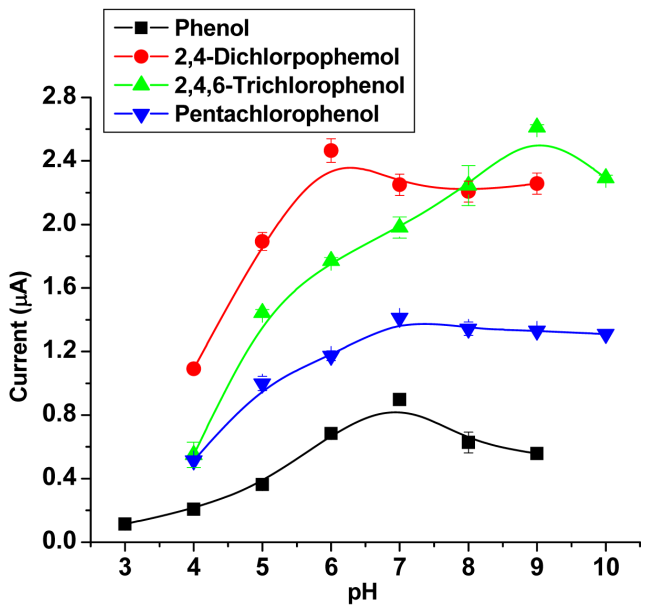

Figure 4. Variation of amperometric current responses with $\mathrm{pH}$ at the SWCNT/GCE for $1 \times 10^{-5} \mathrm{M}$ phenol and $1 \times 10^{-4}$ $M$ for the others; and $E_{\text {applied }}$ for phenol (0.725 V), for 2,4dichlorophenol (0.75 V), for 2,4,6-trichlorophenol, $(0.7 \mathrm{~V})$, and for pentachlorophenol, $(0.8 \mathrm{~V})$, vs $\mathrm{Ag} / \mathrm{AgCl}$; flow rate 1 $\mathrm{mL} / \mathrm{min}$, injection volume $20 \mu \mathrm{L}$.

was constant for each analyte. As it is shown in Figure 5, similar trends were observed for phenol and all chlrophenols. It can be seen that the peak current increases in the range of $0.1-1 \mathrm{~mL} \cdot \mathrm{min}^{-1}$. At low flow rates, the mass transfer of phenolic analytes to the electrode surface is relatively low [52]. Also a broader peak and low resolution were observed. For relatively high flow rates there was a decrease in the flow-injection peak current which is similar to the usual behavior for enzyme-based FIA [50]. At higher flow rates, above $1.2 \mathrm{~mL} \cdot \mathrm{min}^{-1}$, the electron transfer and mass transfer rate are not significantly different. Moreover as the sample passes faster over the electrode the smaller is the fraction of analyte oxidized [36] and as a result the amperometric current

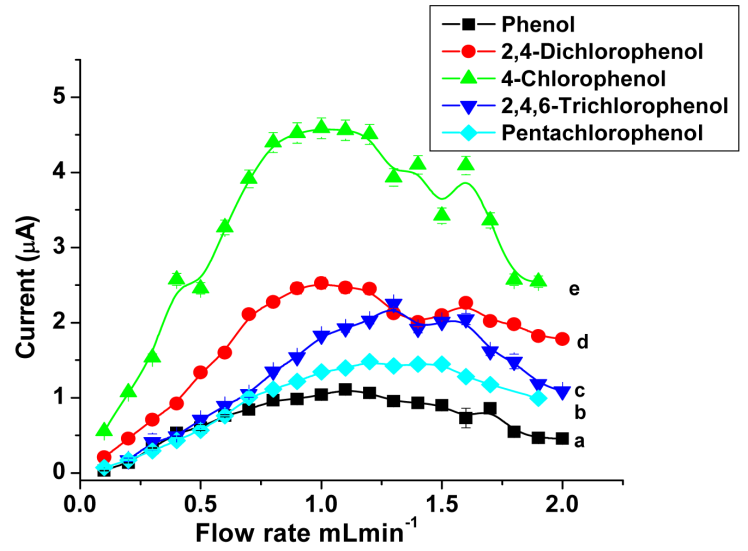

Figure 5. Flow rate dependence of the peak current in FIA: (a) for $1 \times 10^{-5} \mathrm{M}$ Phenol at pH 7, $E_{\text {app }}, 0.725 \mathrm{~V}$, (b) $1 \times 10^{-4}$ M Pentachlorophenol at pH, 7; (c) 2,4,6-Trichlorophenol with at pH 9; (d) 2,4-Dichlorophenol pH 6; (e) 4-Chlorophenol, at pH 6; $E_{\text {app }}$ as in Figure 4; Carrier, 0.1 M sodium acetate.

decreases. The optimum flow rate of the carrier solution for acceptable sharp peaks and sensitivity were in the range of 0.9 and $1.2 \mathrm{~mL} \cdot \mathrm{min}^{-1}$.

\subsubsection{Stability of SWCNT/GCE}

The performance of the SWCNT/GCE as a flow injection detector was found to be remarkably good and the amperometric response of the sensor showed a good stability, since after 20 injections the response remains the same. Figure 6(a) shows the amperometric response measured for 2,4,6-trichlorophenol. At each step $20 \mu \mathrm{L}$ of: $8 \times 10^{-6}$ $\mathrm{M}$ phenol and 4-chlorophenol, $1.5 \times 10^{-5} \mathrm{M}$ 2,4-dichlorophenol, $1 \times 10^{-4} \mathrm{M}$ 2,4,6-trichlorophenol and $1 \times 10^{-5}$ $\mathrm{M}$ pentachlorophenol, were injected. Figure 6(b) shows the operational stability of the amperometric peak current, 


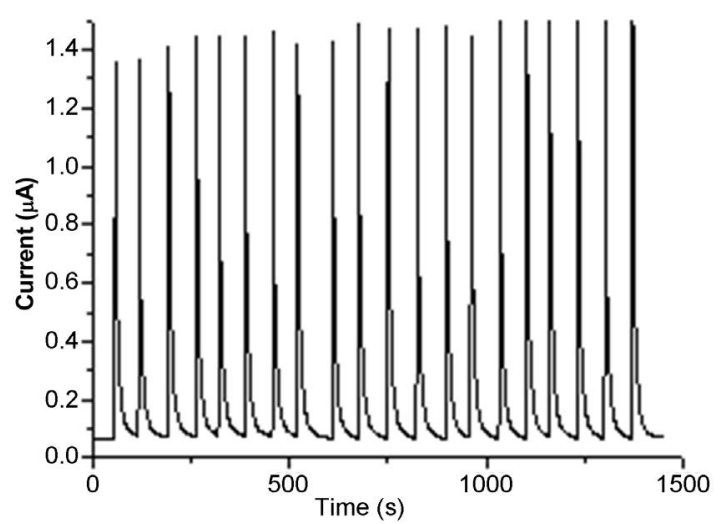

(a)

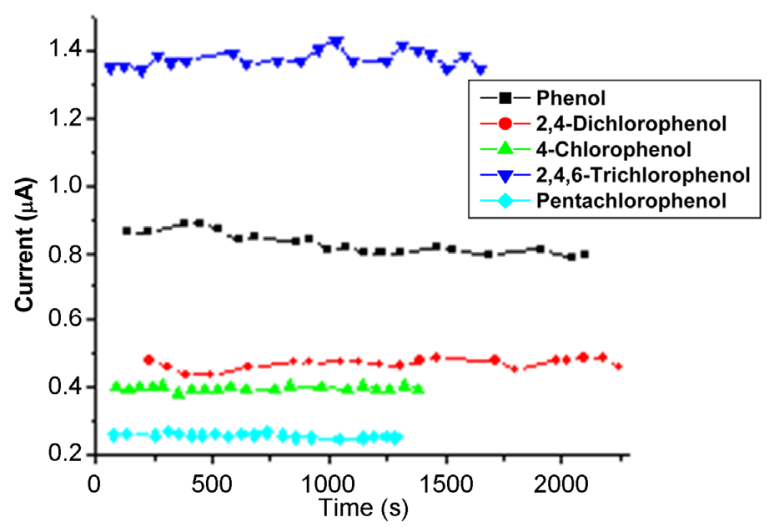

(b)

Figure 6. Amperometric flow injection response of 2,4,6trichlorophenol (a) and stability plot (b) obtained for 20 repetitive injections of $1 \times 10^{-5} \mathrm{M}$ phenol and pentachlorophenol; $6 \times 10^{-5}$ M 4-chlorophenol; $1.5 \times 10^{-5}$ M 2,4-dichlorophenol and $1 \times 10^{-4} \mathrm{M}$ 2,4,6-trichlorophenol at a flow rate: $1.1 \mathrm{~mL} \cdot \mathrm{min}^{-1}$ for phenol, $1 \mathrm{~mL} \cdot \mathrm{min}^{-1}$ for 4 -chlorophenol and 2,4-dichlorophenol, $1.2 \mathrm{~mL} \cdot \mathrm{min}^{-1}$ 2,4,6-trichlorphenol and pentachlorophenol; Other conditions are as in Figure 5.

$i_{\mathrm{p}}$, for 20 successive injections of each analyte. The response had a relative standard deviation ranging between $0.94 \%$ and $3.20 \%$, as shown in Table 1 . These results are due to the fact that flowing liquid solutions continuously clean the surface of the cell and remove the reaction products and impurities leached from the electrode [33, 53]. This experimental results are in good agreement with the stability of CNT modified electrodes [53,54] and different enzymztic biosensor $[36,50]$. Such additional advantages of the flow injection method based on the SWCNT/GCE modified detector broaden the possibilities of determining different phenol derivatives.

\subsubsection{Analytical Performance of the SWCNT/GCE Detector in the Flow Injection System}

In flow injection analysis, the flow-through detection cell monitors the concentration-time profile of the ana- lyte. The behavior of SWCNT/GCE modified electrode was investigated in flow injection for the determination of phenol and different chlorophenls under the optimized conditions. Increasing concentrations of phenol and chlorophenols were injected to the carrier solution $(0.1 \mathrm{M}$ sodium acetate). Figure 7(a) displays the amperometric response of the SWCNT/GCE for 4-chlorophenol and it can be seen that the peak current increases with increasing the concentration of 4-chlorophenol. This wellshaped amperometric peaks indicate that the surface sensing properties of the modified electrode were efficient and reproducible mass transport towards the electrode surface was observed which goes in line with [53, 55]. The amperometric peak heights increase with increase in the concentration of 4-chlorophenol. Figure 7(a) was used to construct the analytical calibration curves of the SWCNT/GCE composite electrode under the optimum experimental conditions for each analyt. Figure 7(b) shows the calibration curve for 4-chlorophenol. Table 2 summarizes the analytical characteristics of the calibration graphs. The limits of detection were calculated on the $3 s_{b} / m$, where $m$ is the slope of the linear calibration graph for each analyte, and $\mathrm{s}_{\mathrm{b}}$ was estimated as the stan-

Table 1. Reproducibility of the stability measurements obtained with SWCNT/GCE in flow-injection analysis.

\begin{tabular}{cc}
\hline Phenolic compounds & RSD value for $i_{p}(\%)$ \\
\hline Phenol & 3.20 \\
4-Chlorophenol & 1.97 \\
2,4-Dichlorophenol & 0.95 \\
2,4,6-Trichlorophenol & 1.93 \\
Pentachlorophenol & 0.94 \\
\hline
\end{tabular}

Table 2. Analytical characteristics of the calibration plots for different phenolic compounds in flow-injection system with the SWCNT/GCE detector.

\begin{tabular}{ccccc}
\hline Phenolic compound & $\begin{array}{c}\text { Linear range } \\
(\mu \mathrm{M})\end{array}$ & $\begin{array}{c}\text { Slope } \\
\left(\mathrm{AM}^{-1}\right)\end{array}$ & $r$ & $\cdot$ \\
\hline Phenol & $0.4-60$ & 0.071 & 0.996 & 0.027 \\
4-Chlorophenol & $0.4-40$ & 0.071 & 0.998 & 0.011 \\
2,4-Dichlorophenol & $0.2-100$ & 0.028 & 0.999 & 0.043 \\
2,4,6-Trichlorophenol & $2-250$ & 0.108 & 0.995 & 0.025 \\
& $0.6-150$ & 0.017 & 0.998 & 0.025 \\
Pentachlorophenol & $150-450$ & 0.553 & 0.996 & \\
\hline
\end{tabular}




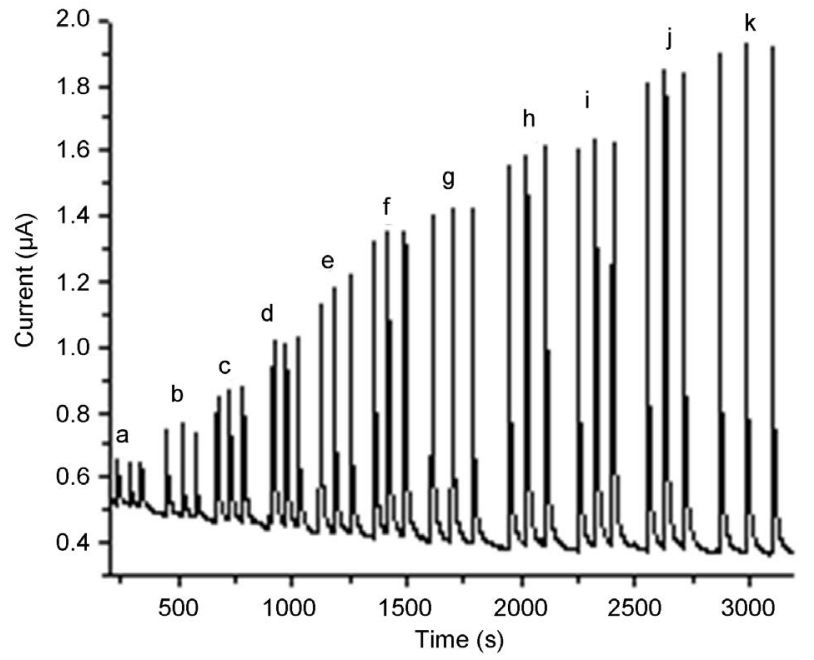

(a)

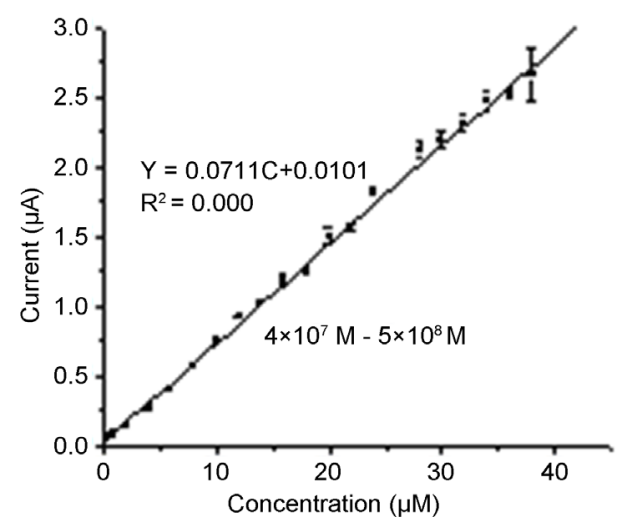

(b)

Figure 7. Amperometric responses for different concentrations of 4-chlorophenol (a-k) of concentrations 2, 4, 6, 8, 9, $10,12,14,16,18,20,22 \mu \mathrm{M}$, respectively (a), and the calibration curves (b), $E_{\text {app }}, 0.8$ vs $\mathrm{Ag} / \mathrm{AgCl}$; flow rate 1.0 $\mathrm{mL} \cdot \mathrm{min}^{-1}$, $\mathrm{pH}, 6$; carrier solution $0.1 \mathrm{M}$ sodium acetate.

dard deviation ( $n=10)$ of the response obtained from the repetitive analyte injections at the lowest concentration. Using this criterion, detection limits ranging between 0.011 and $0.31 \mu \mathrm{M}$ were achieved. As summarized in Table 2, the SWCNT/GCE system used as a detector exhibits a good linear response between the amperometeric peak currents and concentrations of phenol and chlorophenols with low detection limits for all phenolic compounds investigated. The analytical performance of the SWCNT/GCE determined in the flow through system has been compared with other enzyme/enzymeless electrochemical sensors reported recently as shown in Table 3. Characteristics such as, range of linearity, sensitivity and limit of detection achieved and type of electrode were compared. It can be clearly seen from Table 3 that the SWCNT/GCE sensor offers advantages as compared to the other detector designs. Apart from the simplicity in its preparation its dynamic range for the detection of phenolic compounds is wider.

\subsubsection{Interference Studies}

The amperometric response of the SWCNT/GCE modified electrode for to $5 \times 10^{-6}$ phenol was not affected by the addition of $\mathrm{o}$ - and p-nitrophenol up to the concentration of to $5 \times 10^{-4}$, which is in a ratio of 1:100. Above this concentration the peak current increases. Similarly the addition of the same concentrations of 4-chlorophenol, 2,4-dichlorophenol, 2,4,6-trichlorophenol and pentachlorophenol to $5 \times 10^{-6} \mathrm{M}$ phenol has no effect on the amperometric responses of the electrode. With further increase in the concentration of chlorophenols added an increase in the response current was also observed. These can be attributed to their similarity in the optimum operational conditions which resulted in the oxidation of phenolic $\mathrm{OH}$ group. In fact, the selectivity of most commonly used amperometric biosensors such as tyrosinase, laccase, and peroxidase, modified electrodes for phenolic compounds are relatively higher due to the use of low applied potentials [35]. The SWCNT/GCE modified electrode needs higher potential to be able to oxidize the phenol; therefore the risk of electro-oxidation interfering compounds in the sample is higher.

\subsubsection{Analytical Application}

The analytical applications of the modified electrode were investigated within the linear range. With phenol as the analyte the estimation of content was carried out by injecting a $2 \mu \mathrm{M}$ phenol to deionizzed water. Increased concentrations of phenol were injected and the amperometric responses were recorded which were used for recovery calculations. As shown in Table 4 the recoveries were between $99.7 \%$ and $108.36 \%$, which confirm the designed electrode used in the method is reliable for quantitative determination of phenol and chlorophenols.

\section{Conclusion}

In this paper, we presented one simple and low cost electrochemical sensor based on SWCNT modified GCE for the analysis of phenol and chlorophenols using flow injection amperometric methods. The SWCNT modified electrode has a great role in minimizing of surface fouling due to its high electrocatalytic activity. The analytical performance obtained after optimizing experimental variables was impressive, and the electrode has a good operational stability, linear range and detection limits. Although the sensor has limited selectivity for these analytes, the electrode is simple in its preparation.

\section{Acknowledgements}

Negussie Negash is grateful to the Graduate School of 
Table 3. Comparison of analytical performance of the calibration curves of SWCNT/GCE with different modified electrodes for phenol, 4-chlorophenol, 2,4,6-trichlorophenol, and pentachlorophenol.

\begin{tabular}{|c|c|c|c|c|c|}
\hline Phenolic substrate & Detector & $\begin{array}{l}\text { Linear-range } \\
\qquad(\mu \mathrm{M})\end{array}$ & Sensitivity & $\begin{array}{r}\text { Detection } \\
\text { limit }(\mu \mathrm{M})\end{array}$ & Reference \\
\hline \multirow{7}{*}{ Phenol } & self-assembled monolayer based tyrosinase on $\mathrm{Au}$ & $2-200$ & $13.9 \mathrm{nA} / \mu \mathrm{M}$ & 0.088 & 50 \\
\hline & laccase- and tyrosinase-based biosensors & $1-10$ & $0.091 \mathrm{nA} / \mu \mathrm{M}$ & 0.15 & 57 \\
\hline & $\begin{array}{l}\text { multiwalled carbon nanotube-poly(pyrrole)-horseradish } \\
\text { peroxidase nanobiocomposite }\end{array}$ & $16-44$ & $1 \mathrm{nA} / \mu \mathrm{M}$ & 3.52 & 37 \\
\hline & $\begin{array}{l}\text { GCE modified with multi-wall carbon nanotubes } \\
\text { dispersed in polyethylenimine }\end{array}$ & $2.5-20$ & $27 \mathrm{nA} / \mu \mathrm{M}$ & 0.21 & 11 \\
\hline & $\begin{array}{l}\text { MWNT-Nafion-Tyr nanobiocomposite film modified } \\
\text { glassy carbon electrode }\end{array}$ & $1-19$ & $303 \mu \mathrm{A} / \mathrm{mM}$ & 0.13 & 34 \\
\hline & $\begin{array}{c}\text { biofunctional } \mathrm{ZnO} \text { nanorod microarrays on the nano-crystalline } \\
\text { diamond electrode }\end{array}$ & $1-150$ & $287.1 \mu \mathrm{A} / \mathrm{mMcm}^{2}$ & 0.25 & 58 \\
\hline & SWCNT/GCE & $0.4-60$ & $71 \mathrm{nA} / \mu \mathrm{M}$ & 0.027 & This paper \\
\hline \multirow{5}{*}{ 4-Chlorophenol } & self-assembled monolayer-based tyrosinase biosensors on $\mathrm{Au}$ & $0.4-40$ & & 0.15 & 50 \\
\hline & laccase- and tyrosinase-based biosensors & $1-10$ & $0.131 \mathrm{nA} / \mu \mathrm{M}$ & 0.09 & 57 \\
\hline & $\begin{array}{l}\text { multiwalled carbon nanotube-poly(pyrrole)-horseradish } \\
\text { peroxidase nanobiocomposite }\end{array}$ & $1.6-14.4$ & $8 \mathrm{nA} / \mu \mathrm{M}$ & 0.3 & 37 \\
\hline & $\begin{array}{l}\text { biofunctional } \mathrm{ZnO} \text { nanorod microarrays on the } \\
\text { nanocrystalline diamond electrode }\end{array}$ & $1-150$ & $339.3 \mu \mathrm{A} / \mathrm{mMcm}^{2}$ & 0.2 & 58 \\
\hline & SWCNT/GCE & $0.4-40$ & $71 \mathrm{nA} / \mu \mathrm{M}$ & 0.011 & This paper \\
\hline \multirow{2}{*}{ 2,4,6-Trichloropenol } & Enzymless GCE using preoxidation & $0.4-750$ & Not available & 0.004 & 52 \\
\hline & SWCN/GCE & $0.2-100$ & $108 \mathrm{nA} / \mu \mathrm{M}$ & 0.025 & This paper \\
\hline \multirow{2}{*}{ Pentachlorophenol } & MWCNT/Epoxy composite & $2-12$ & $11 \mu \mathrm{A} / \mu \mathrm{M}$ & 0.803 & 56 \\
\hline & SWCNT/GCE & $0.6-450$ & $17 \mathrm{nA} / \mu \mathrm{M}$ & 0.025 & This paper \\
\hline
\end{tabular}

Table 4. Phenol determination.

\begin{tabular}{cccc}
\hline Sample $(\mu \mathrm{M})$ & Added $(\mu \mathrm{M})$ & Found $(\mu \mathrm{M})$ & Recoveries \\
\hline 2 & 1.5 & 3.49 & 99.7 \\
2 & 4.5 & 6.66 & 102.46 \\
2 & 6.5 & 8.49 & 99.88 \\
2 & 9 & 11.92 & 108.36 \\
\hline
\end{tabular}

Addis Ababa University, for financial support and the National University of Lesotho for giving him the chance to use the resources and facilities of their research laboratory.

\section{REFERENCES}

[1] I. E. Mülazımoğlu, A. D. Mülazımoğlu and E. Yılmaz, "Determination of Quantitative Phenol in Tap Water Samples as Electrochemical Using 3,3'-Diaminobenzidine Modified Glassy Carbon Sensor Electrode,” Desalination, Vol. 268, No. 1, 2011, pp. 227-232. http://dx.doi.org/10.1016/j.desal.2010.10.033
[2] C. B. Jacobs, M. J. Peairs and B. J. Venton, "Review: Carbon Nanotube Based Electrochemical Sensors for Biomolecules,” Analytica Chimica Acta, Vol. 662, No. 2, 2010, pp. 105-127. http://dx.doi.org/10.1016/j.aca.2010.01.009

[3] K. Balasubramanian and M. Burghard, "Biosensors Based on Carbon Nanotubes," Analytical and Bioanalytical Chemistry, Vol. 385, No. 3, 2006, pp. 452-468.

http://dx.doi.org/10.1007/s00216-006-0314-8

[4] S. K. Vashist, D. Zheng, K. Al-Rubeaan, J. H. T. Luong and F.-S. Sheu, "Advances in Carbon Nanotube Based Electrochemical Sensors for Bioanalytical Applications," Biotechnology Advancement, Vol. 29, No. 2, 2011, pp. 169-188. http://dx.doi.org/10.1016/j.biotechadv.2010.10.002

[5] D. W. H. Fam, A. I. Palaniappan, A. I. Y. Tok, B. Liedberg and S. M. Moochhala, "A Review on Technological Aspects Influencing Commercialization of Carbon Nanotube Sensors," Sensors and Actuators B, Vol. 157, No. 1, 2011, pp. 1-7. http://dx.doi.org/10.1016/j.snb.2011.03.04

[6] K. Scida, P. W. Stege, G. Haby, G. A. Messina and C. D. García, "Recent Applications of Carbon-Based Nanoma- 
terials in Analytical Chemistry: Critical Review,” Analytica Chimica Acta, Vol. 69, No. 1, 2011, pp. 6-17. http://dx.doi.org/10.1016/j.aca.2011.02.025

[7] P. Yanez-Sedeno, J. Riu, J. M. Pingarron and F. X. Rius, "Electrochemical Sensing Based on Carbon Nanotubes," TrAc-Trends in Analytical Chemistry, Vol. 29, No. 9, 2010, pp. 939-953. http://dx.doi.org/10.1016/j.trac..2010.06.00

[8] A. J. Ahammad, J. Lee and M. A. Rahman, "Electrochemical Sensors Based on Carbon Nanotubes," Sensors, Vol. 9, No. 1, 2009, pp. 2289-2319. http://dx.doi.org/10.3390/s90402289

[9] J. Wang, R. P. Deo and M. Musameh, "Stable and Sensitive Electrochemical Detection of Phenolic Compounds at Carbon Nanotube Modified Glassy Carbon Electrodes,” Electroanalysis, Vol. 15, No. 23-24, 2003, pp. 1830-1834. http://dx.doi.org/10.1002/elan.200302772

[10] Q. Zhao, L. Guan, Z. Gu and Q. Zhuang, "Determination of Phenolic Compounds Based on the Tyrosinase-Single Walled Carbon Nanotubes Sensor,” Electroanalysis, Vol. 17, No. 1, 2005, pp. 85-88. http://dx.doi.org/10.10.10.1002/elan.200403123

[11] A. S. Arribas, E. Bermejo, M. Chicharro, A. Zapardiel, G. L. Luque, N. F. Ferreyra and G. A. Rivas, "Analytical Applications of Glassy Carbon Electrodes Modified with Multi-Wall Carbon Nanotubes Dispersed in Polyethylenimine as Detectors in Flow Systems," Analytica Chimica Acta, Vol. 596, No. 2, 2007, pp. 183-194. http://dx.doi.org/10.1016/j.aca.2007.06.014

[12] S. Sundaram and S. K. Annamalai, "Selective Immobilization of Hydroquinone on Carbon Nanotube Modified Electrode via Phenol Electro-Oxidation Method and Its Hydrazine Electro-Catalysis and Escherichia Coli Antibacterial Activity,” Electrochimica Acta, Vol. 62, 2012, pp. 207-217. http://dx.doi.org/10.1016/j.electacta.2011.12.044

[13] M. Naczk and F. Shahidi, "Phenolics in Cereals, Fruits and Vegetables: Occurrence, Extraction and Analysis," Journal of Pharmaceutical and Biomedical Analysis, Vol. 41, No. 5, 2006, pp. 1523-1542. http://dx.doi.org/10.1016/j.jpba.2006.04.002

[14] A. Simic, D. Manojlovic, D. Segan and M. Todorovic, "Electrochemical Behavior and Antioxidant and Prooxidant Activity of Natural Phenolics,” Molecules, Vol. 12, No. 10 , 2007, pp. 2327-2340. http://dx.doi.org/10.3390/12102327

[15] C. Proestos, D. Sereli and M. Komaitis, "Determination of Phenolic Compounds in Aromatic Plants by RP-HPLC and GC-MS," Food Chemistry, Vol. 95, No. 1, 2006, pp. 44-52. http://dx.doi.org/10.1016/j.foodchem.2004.12.016

[16] A. S. Arribas, M. Martınez-Fernandez and M. Chicharro, "The Role of Electroanalytical Techniques in Analysis of Polyphenols in Wine," TrAc Trends in Analytical Chemistry, Vol. 34, 2012, pp. 78-96. http://dx.doi.org/10.1016/j.trac.2011.10.015

[17] A. Penalver, E. Pocurull, F. Borrull and R. M. Marce, "Solid-Phase Microextraction Coupled to High-Performance Liquid Chromatography to Determine Phenolic Compounds in Water Samples,” Journal of Chromatogra- phy A, Vol. 953, No. 1-2, 2002, pp. 79-87. http://dx.doi.org/10.1016/S0021-9673(02)00113-9

[18] G. W. Muna, V. Quaiserova-Mocko and G. M. Swain, "The Analysis of Chlorinated Phenol Solutions by Capillary Electrophoresis Coupled with Direct and Indirect Amperometric Detection Using a Boron-Doped Diamond Microelectrode,” Electroanalysis, Vol. 17, No. 13, 2005, pp. 1160-1170. http://dx.doi.org/10.1002/elan.200403230

[19] "Phenols in Federal Register: Environment Protection Agency Method 604,” Part VIII, 40 CFR Part 136, 1984, pp. 58-66.

[20] "Phenols by Gas Chromatography, Capillary Column Technique: Environment Protection Agency Method 804," Part 1, Washington DC, 1995, pp. 1-28.

[21] D. Puig and D. Barcelo, "Determination of Phenolic Compounds in Water and Waste Water," TrAc Trends in Analytical Chemistry, Vol. 15, No. 8, 1996, pp. 362-365. http://dx.doi.org/10.1016/0165-9936(96)00057-X

[22] J.-S. Park, M. T. Brown and T. Han, "Phenol Toxicity to the Aquatic Macrophyte Lemna Paucicostata," Aquatic Toxicology, Vol. 106-107, 2012, pp. 182-188. http://dx.doi.org/10.1016/j.aquatox.2011.10.004

[23] M. Krizman, D. Baricevic and M. Prosek, "Determination of Phenolic Compounds in Fennel by HPLC and HPLCMS Using a Monolithic Reversed-Phase Column," Journal of Pharmaceutical and Biomedical Analysis, Vol. 43 No. 2, 2007, pp. 481-485. http://dx.doi.org/10.1016/j.jpba.2006.07.029

[24] M. Tasioula-Margari and O. Okogeri, "Simultaneous Determination of Phenolic Compounds and Tocopherols in Virgin Olive Oil Using HPLC and UV Detection,” Food Chemistry, Vol. 74, No. 3, 2001, pp. 377-383. http://dx.doi.org/10.1016/S0308-8146(01)00176-5

[25] F. Zhou, X. Li and Z. Zeng, "Determination of Phenolic Compounds in Wastewater Samples Using a Novel Fiber by Solid-Phase Microextraction Coupled to Gas Chromatography,” Analytica Chimica Acta, Vol. 538, No. 1-2, 2005, pp. 63-70. http://dx.doi.org/10.1016/j.aca.2005.02.009

[26] Y. Liang, W. Cao, W.-J. Chen, X.-H. Xiao and J.-B. Zheng, "Simultaneous Determination of Four Phenolic Components in Citrus Honey by High Performance Liquid Chromatography Using Electrochemical Detection,” Food Chemistry, Vol. 114, No. 4, 2009 pp. 1537-1541. http://dx.doi.org/10.1016/j.foodchem.2008.11.024

[27] E. Hurtado-Fernández, M. Gómez-Romero, A. CarrascoPancorbo and A. Fernández-Gutiérrez, "Application and Potential of Capillary Electroseparation Methods to Determine Antioxidant Phenolic Compounds from Plant Food Material," Journal of. Pharmaceutical and Biomedical Analysis, Vol. 53, No. 5, 2010, pp. 1130-1160. http://dx.doi.org/10.1016/j.jpba.2010.07.028

[28] A. M. Naley, "Analysis of Phenols in Sea Water by Fluorometry: Direct Analysis of the Water Phase," Bulletin of Environmental Contamination and Toxicology, Vol. 3, No. 4, 1983, pp. 494-500. http://dx.doi.org/10.1007/BF01622283

[29] Y. Tsuruta, S. Watanabe and H. Inoue, "Fluorometric De- 
termination of Phenol and p-Cresol in Urine by Precolumn High-Performance Liquid Chromatography Using 4-(N-Phthalimidinyl)benzenesulfonyl Chloride," Analytical Biochemistry, Vol. 243, No. 1, 1996, pp. 86-91. http://dx.doi.org/10.1006/abio.1996.0485

[30] M. Trojanowicz, "Recent Developments in Electrochemical Flow Advantages Detections-A Review Part II. Liquid Chromatography," Analytica Chimica Acta, Vol. 688, No. 1, 2011, pp. 8-35.

http://dx.doi.org/10.1016/j.aca.2010.12.024

[31] B. Fuhrmann and U. Spohn, "An Enzymatic Amplification Flow Injection Analysis (FIA) System for the Sensitive Determination of Phenol," Biosensor and Bioelectronics, Vol. 13, No. 7-8, 1998, pp. 895-902. http://dx.doi.org/10.1016/S0956-5663(98)00061-X

[32] F. Maya, J. M. Estela and V. Cerdà, "Flow Analysis Techniques as Effective Tools for the Improved Environmental Analysis of Organic Compounds Expressed as Total Indices,” Talanta, Vol. 81, No. 1-2, 2010, pp. 1-8. http://dx.doi.org/10.1016/j.talanta.2010.01.028

[33] E. J. Liorent-Martinez, P. Ortega-Barrales, M. L. Fernandez de Cordova and A. Ruiz-Mendina, "Trends in FlowBased Analytical Methods Applied to Pesticide Detection: A Review,” Analytica Chimica Acta, Vol. 684, No. 1-2, 2011, pp. 30-39. http://dx.doi.org/10.1016/j.aca.2010.10.036

[34] Y.-C. Tsai and C.-C. Chiu, "Amperometric Biosensors Based on Multiwalled Carbon Nanotube-Nafion-Tyrosinase Nanobiocomposites for the Determination of Phenolic Compounds," Sensors and Actuators B, Vol. 125, No. 1, 2007, pp. 10-16.

http://dx.doi.org/10.1016/j.snb.2007.01.032

[35] B. Haghighi, L. Gorton, T. Ruzgas and L. J. Jönsson, "Characterization of Graphite Electrodes Modified with Laccase from Trametes versicolor and Their Use for Bioelectrochemical Monitoring of Phenolic Compounds in Flow Injection Analysis," Analytica Chimica Acta, Vol. 487, No. 1, 2003, pp. 3-14.

http://dx.doi.org/10.1016/S0003-2670(03)00077-1

[36] R. S. Freire, N. Duran and L. Kubota, "Development of a Laccases-Based Flow Injection Electrochemical Biosensor for the Determination of Phenolic Compounds and Its Application for Monitoring Remediation of Kraft EI Paper Mill Effluent,” Analytica Chimica Acta, Vol. 463, No. 2, 2002, pp. 229-238. http://dx.doi.org/10.1016/S0003-2670(02)00417-8

[37] S. Korkut, B. Keskinler and E. Erhan, “An Amperometric Biosensor Based on Multiwalled Carbon NanotubePoly(pyrrole)-horseradish Peroxidase Nanobiocomposite Film for Determination of Phenol Derivatives," Talanta, Vol. 76, No. 5, 2008, pp. 1147-1152. http://dx.doi.org/10.1016/j.talanta.2008.05.016

[38] S. K. Ozoner, F. Yilmaz, A. Celik, B. Keskinler and E. Erhan, "A Novel Poly(Glycine methacrylate-co-3-thienylmethyl methacrylate)-polypyrrole-carbon Nanotube-Horseradish Peroxidase Composite Film Electrode for the Detection of Phenolic Compounds," Current Applied Physics, Vol. 11, No. 3, 2011, pp. 402-408. http://dx.doi.org/10.1016/j.cap.2010.08.010
[39] R. Solna and P. Skladal, “Amperometric Flow-Injection Determination of Phenolic Compounds Using a Biosensor with Immobilized Laccase, Peroxidase and Tyrosinase,” Electroanalysis, Vol. 17, No. 23, 2005, pp. 2137-2146. http://dx.doi.org/10.1002/elan.200403343

[40] A. Sassolas, L. J. Blum and B. D. Leca-Bouvier, "Immobilization Strategies to Develop Enzymatic Biosensors," Biotechnology Advances, Vol. 30, No. 3, 2012, pp. 489511. http://dx.doi.org/10.1016/j.biotechadv.2011.09.003

[41] J. Kulys and R. Vidziunaite, “Amperometric Biosensors Based on Recombinant Laccases for Phenols Determination,” Biosensors and. Bioelectronics, Vol. 18, No. 2-3, 2003, pp. 319-325. http://dx.doi.org/10.1016/S0956-5663(02)00172-0

[42] L.-S. Duan, F. Xie, F. Zhou and S.-F. Wang, "The Electrochemical Behavior of Acetaminophen on Multi-Walled Carbon Nanotubes Modified Electrode and Its Analytical Application,” Analytical Letters, Vol. 40, No. 14, 2007, pp. 2653-2663. http://dx.doi.org/10.1080/00032710701588341

[43] M. A. Heras, S. Lupu, L. Pigani, C. Pirvu, R. Seeber, F. Terzi and C. Zanardi, “A poly(3,4-ethylenedioythiophene)poly(styrne sulphonate) Composite Electrode Coating in the Electrooxidation of Phenol," Electrochimica Acta, Vol. 50, No. 7-8, 2005, pp. 1685-1691. http://dx.doi.org/10.1016/j.electacta.2004.10.029

[44] M. Ferreira, H. Varela, R. M. Torresi and G. TremiliosiFilho, "Electrode Passivation Caused by Polymerization of Different Phenolic Compounds,” Electrochimica Acta, Vol. 52, No. 2, 2006, pp. 434-442.

http://dx.doi.org/10.1016/j.electacta.2006.05.025

[45] T. Spataru and N. Spataru, "Voltammetric Detection of Phenol at Platinum-Polytyramine Composite Electrodes in Acidic Media,” Journal of Hazardous Materials, Vol. 180, No. 1-3, 2010, pp. 777-780. http://dx.doi.org/10.1016/j.jhazmat.2010.04.058

[46] T. A. Enache and A. M. Oliveira-Brett, "Phenol and ParaSubstituted Phenols Electrochemical Oxidation Pathways,” Journal of Electroanalytical Chemistry, Vol. 655, No. 1, 2011, pp. 9-16. http://dx.doi.org/10.1016/j.jelechem.2011.02.022

[47] M. Pohanka and P. Skladal, "Electrochemical Biosensors -Principles and Applications", Journal of Applied Biomedicine, Vol. 6, No. 2, 2008, pp. 57-64.

[48] J. Wang, "Carbon Nanotube Based Electrochemical Biosensors: A Review,” Electroanalysis, Vol. 17, No. 1, 2005, pp. 7-14. http://dx.doi.org/10.1002/elan.200403113

[49] A. S. Santos, A. C. Pereira, M. D. P. T. Sotomayor, C. R. T. Tarley, N. D. Lauro and T. Kubota, "Determination of Phenolic Compounds Based on Co-Immobilization of Methylene Blue and HRP on Multi-Wall Carbon Nanotubes” Electroanalysis, Vol. 19, No. 5, 2007, pp. 549554. http://dx.doi.org/10.1002/elan.200603759

[50] S. Campuzano, B. Serra, M. Pedrero, F. J. M. Villena and J. M. Pingarrón, “Amperometric Flow-Injection Determination of Phenolic Compounds at Self-Assembled Monolayer-Based Tyrosinase Biosensors," Analytica Chimica Acta, Vol. 494, No. 1-2, 2003, pp.187-197. http://dx.doi.org/10.1016/S0003-2670(03)00919-X 
[51] T. E. Barman, "Enzyme Handbook,” Springer, New York, 1985.

[52] J.-S. Wang, P.-Y. Chen, T.-T. Huang and M.-S. Lin, "Enzymeless Flow Injection Analysis of 2,4,6-Trichlorophenol Based on Preoxidation by Ammonium Cerium (IV) Nitrate,” International Journal of Electrochemical Science, Vol. 7, No. 10, 2012, pp. 9113-9121.

[53] S. K. Ozoner, M. Yalvac and E. Erhan, "Flow Injection Determination of Catechol Based on Polypyrrole-Carbon Nanotube-Tyrosinase Biocomposite Detector," Current Applied Physics, Vol. 10, No. 1, 2010, pp. 323-328. http://dx.doi.org/10.1016/j.cap.2009.06.017

[54] D. Vega, L. Agui, A. Gonzalez-Cortes, P. Yanez-Sedeno and J. M. Pingarron, "Electrochemical Detection of Phenolic Estrogenic Compounds at Carbon Nanotube-Modified Electrodes,” Talanta, Vol. 71, No. 3, 2007, pp. 1031-1038.

http://dx.doi.org/10.1016/j.talanta.2006.05.071

[55] K. Schachl, H. Alemu, K. Kalcher, J. Jezkova, I. Svanvara and K. Vytras, "Amperometric Determination of Hydrogen Peroxide with a Manganese Dioxide-Modified
Carbon Paste Electrode Using Flow Injection Analysis," Analyst, Vol. 122, No. 9, 1997, 985-989.

http://dx.doi.org/10.1039/a701723e

[56] A. Remes, A. Pop, F. Manea, A. Baciu, S. J. Picken and J. Schoonman, "Electrochemical Determination of Pentachlorophenol in Water on a Multi-Wall Carbon NanotubesEpoxy Composite Electrode,” Sensors, Vol. 12, No. 6, 2012, pp. 7033-7046. http://dx.doi.org/10.3390/s120607033

[57] R. S. Freire, N. Durán and L. T. Kubota, "Electrochemical Biosensor-Based Devices for Continuous Phenols Monitoring in Environmental Matrices," Journal of Brazilian Chemical Society, Vol. 13, No. 4, 2002, pp. 456462.

http://dx.doi.org/10.1590/S0103-50532002000400008

[58] J. W. Zhao, D. H. Wu and J. F. Zhi, “A Novel Tyrosinase Biosensor Based on Biofunctional ZnO Nanorod Microarrays on the Nanocrystalline Diamond Electrode for Detection of Phenolic Compounds," Bioelectrochemistry, Vol. 75, No. 1, 2009, pp. 44-49.

http://dx.doi.org/10.1016/j.bioelechem.2009.01.005 